\title{
IfIISGUC.ORG
}

"İ̦, GÜç" ENDÜSTRi iLIȘKiLERi VE inSAN KAYNAKLARI DERGisi

"IS, GUC" INDUSTRIAL RELATIONS AND HUMAN RESOURCES JOURNAL

\section{Broadening Our Research and Action Agenda: Cherishing and Revering Women}

\author{
Ronald J. BURKE \\ York University
}

Ekim/October 2010, Cilt/Vol: 12, Say1/Num: 4, Page:93-107

ISSN: 1303-2860, DOI: 10.4026/1303-2860.2010.160.x

Makalenin on-line kopyasına erişmek için:

http://www.isguc.org/?p=article\&id=423\&vol=12\&num=4\&year=2010

To reach the on-line copy of article:

http://www.isguc.org/?p=article\&id=423\&vol=12\&num=4\&year=2010

Makale İçin İletişim/Correspondence to: 
(C) 2000- 2010

"İşGüç" Endüstri İlişkileri ve İnsan Kaynakları Dergisi

"İşGüç" Industrial Relations and Human Resources Journal

Ekim/October 2010, Cilt/Vol: 12, Say1/Num: 4

ISSN: 1303-2860, DOI: 10.4026/1303-2860.2010.160.x

Editör/Editor-in-Chief

Aşkın Keser (Kocaeli University)

Editör Yardımcıları/Co-Editors

K.Ahmet Sevimli (Uludağ University)

Gözde Yılmaz (Kocaeli University)

Uygulama/Design

Yusuf Budak (Kocaeli Universtiy)

\author{
Yayın Kurulu / Publishing Committee \\ Dr.Zerrin Firat (Uludăg University) \\ Doç.Dr.Aşkın Keser (Kocaeli University) \\ Prof.Dr.Ahmet Selamoğlu (Kocaeli University) \\ Yrd.Doç.Dr.Ahmet Sevimli (Uludağ University) \\ Yrd.Doç.Dr.Abdulkadir Şenkal (Kocaeli University) \\ Yrd.Doç.Dr.Gözde Yilmaz (Kocaeli University) \\ Dr.Memet Zencirkıran (Uludağ University)
}

Uluslararası Danışma Kurulu / International Advisory Board

Prof.Dr.Ronald Burke (York University-Kanada)

Assoc.Prof.Dr.Glenn Dawes (James Cook University-Avustralya)

Prof.Dr.Jan Dul (Erasmus University-Hollanda)

Prof.Dr.Alev Efendioğlu (University of San Francisco-ABD)

Prof.Dr.Adrian Furnham (University College London-İngiltere)

Prof.Dr.Alan Geare (University of Otago- Yeni Zellanda)

Prof.Dr. Ricky Griffin (TAMU-Texas AEM University-ABD)

Assoc. Prof. Dr. Diana Lipinskiene (Kaunos University-Litvanya)

Prof.Dr.George Manning (Northern Kentucky University-ABD)

Prof. Dr. William (L.) Murray (University of San Francisco-ABD)

Prof.Dr.Mustafa Özbilgin (University of East Anglia-UK)

Assoc. Prof. Owen Stanley (James Cook University-Avustralya)

Prof.Dr.Işık Urla Zeytinoğlu (McMaster University-Kanada)

Danışma Kurulu / National Advisory Board

Prof.Dr.Yusuf Alper (Uludağ University)

Prof.Dr.Veysel Bozkurt (Uludağ University)

Prof.Dr.Toker Dereli (Işık University)

Prof.Dr.Nihat Erdoğmuş (Kocaeli University)

Prof.Dr.Ahmet Makal (Ankara University)

Prof.Dr.Ahmet Selamoğlu (Kocaeli University)

Prof.Dr.Nadir Suğur (Anadolu University)

Prof.Dr.Nursel Telman (Maltepe University)

Prof.Dr.Cavide Uyargil (İstanbul University)

Prof.Dr.Engin Yildırım (Sakarya University)

Doç.Dr.Arzu Wasti (Sabancı University)

Dergide yayınlanan yazllardaki görüşler ve bu konudaki sorumluluk yazarlarına aittir.

Yayınlanan eserlerde yer alan tüm içerik kaynak gösterilmeden kullanılamaz.

All the opinions written in articles are under responsibilities of the outhors.

None of the contents published can't be used without being cited. 


\title{
Broadening Our Research and Action Agenda: Cherishing and Revering Women*
}

\author{
Ronald J. BURKE \\ York University
}

\begin{abstract}
:
have been researching and writing about the experiences of women in management with several colleagues (e.g., Marilyn Davidson, Susan Vinnicombe, Mary Mattis, Debra Nelson, among others) and advocating on women's behalf with organizational clients for over 20 years.

Marilyn Davidson and I edited a volume (Davidson \& Burke, 2004) containing chapters reporting on the status of women in management and the professions in 20 countries, chapters being written in 2003. Chapters included information on each country's labor force characteristics, women pursuing education, women in management and women on boards of directors, country legislation supporting women's advancement, organizational initiatives supporting women's career advancement, and projections for the future. These contributions represented countries most likely to be active in supporting managerial and professional women and collecting data on the status of women in the workforce. Many countries still do not have such information. We found (Davidson \& Burke, 2004, Chapter 1) considerable variation among countries represented in such things as the percentage of the labor force that is female, percentage of managers and professionals that are women, legislation supporting women's advancement, and organizational efforts to develop and advance women.
\end{abstract}

Keywords: Women , Management, Labor Force

\footnotetext{
* Preparation of this manuscript was supported in part by York University. I acknowledge my colleague, Marilyn Davidson, in the preparation of this manuscript.
} 
"The world is awakening to a powerful truth: women and girls aren't the problem; they're the solution" Nicholas D. Kristoff and Sheryl WuDunn (2009)

I have been researching and writing about the experiences of women in management with several colleagues (e.g., Marilyn Davidson, Susan Vinnicombe, Mary Mattis,

Debra Nelson, among others) and advocating on women's behalf with organizational clients for over 20 years.

Marilyn Davidson and I edited a volume (Davidson \& Burke, 2004) containing chapters reporting on the status of women in management and the professions in 20 countries, chapters being written in 2003. Chapters included information on each country's labor force characteristics, women pursuing education, women in management and women on boards of directors, country legislation supporting women's advancement, organizational initiatives supporting women's career advancement, and projections for the future.

These contributions represented countries most likely to be active in supporting managerial and professional women and collecting data on the status of women in the workforce. Many countries still do not have such information. We found (Davidson \& Burke, 2004, Chapter 1) considerable variation among countries represented in such things as the percentage of the labor force that is female, percentage of managers and professionals that are women, legislation supporting women's advancement, and organizational efforts to develop and advance women.

There were some positive aspects in the 20 countries. These included:

+ more women in management and in the professions (Burke \& Mattis, 2009, 2005; Burke \& Nelson, 2002).

*more women on corporate boards of directors (Burke \& Mattis, 2000; Vinnicombe, Singh, Burke, Bilimoria \& Huse, 2009)

+ more supportive government policies

+more supportive organizational practices (Catalyst, 1998)

+changing family roles and responsibilities

+availability of more widespread support systems

+improved economic and labor market conditions for women

+changes in demographic characteristics offering more opportunities for women

But there were also several negative aspects across the 20 countries. These included the following.

+the pace of change was slow

+ men still dominated senior executive positions, CEO jobs and corporate board directorships

+women still faced discrimination and gender, ethnic, cultural and religious stereotyping

+in some countries (e.g., Australia, UK, Canada, and Norway) proportions of women as managers seemed to have plateaued. In Norway, for example, it was estimated that it would take another 115 years before women and men were equally represented on corporate boards of directors. 
This left us with the question of whether the cup was half full or half empty. Were the status reports provided by these advanced countries evidence of interest and progress in the development and advancement of women? These countries were clearly the "best" countries as far as women's progress was concerned. Whether one used the metaphors of a glass ceiling (Barreto, Ryan \& Schmitt, 2009), concrete walls, sticky floors, or a labyrinth (Eagly \& Carli, 2009), women's advancement had fallen short of expectations.

Marilyn Davidson and I (Davidson \& Burke, 2010) are currently in the process of updating our 2004 collection in the same 20 countries using the same areas of content; six years having passed since our first effort.. This 2010 collection allowed us to take stock of where we have been and where we are today. Here is a sneak preview of what we found Some progress had taken place, but it continues to be limited and uneven.. There was also variation across the 20 countries as well. It may be that the 6 years time period was too short to indicate signs of real progress. Or it also may be that we are still falling short in our various efforts to support the advancement of qualified women in the ranks of management and the professions. Again the cup half full or half empty question.

As this collection was being put together, stories about the experiences, and in some cases plight, of women appeared. These stories, as often as not, referred to women in the workforce other than managers and professionals and from a variety of countries, most not included in our collections. These stories placed our work on managerial and professional women into a broader worldwide context and seemed to shed some light on the limited gains we observed in our two collections.

\section{Getting beyond the facts and statistics}

I would like to get behind the numbers and focus on the tangible "flesh and blood" experiences of women and men in several countries through events and stories reported in the media. It should be clearly noted that my sample of stories and events is nonrandom and may not represent the experiences of women and men in the workplace world-wide. These stories mostly appeared in Toronto newspapers and obviously did not contain examples of successes experienced by women in many countries as well as difficulties faced by women in these same countries. And while my interest to date has focused on managerial and professional women for the most part, relatively elite, educated, successful and privileged women, my stories also include the experiences of women and men in general.

\section{First the good news.}

\section{Some firsts}

A Canadian woman, Stacey Allister, replaced a man, Larry Scott, as CEO of the Women's Tennis Association.

In June 2009, Venice appointed its first female gondolier, Giorgia Boscoli, their first female gondolier in 900 years.

The appointment and confirmation of Judge Sonia Sotomayor, a Latina woman, by President Barack Obama as his Supreme Court nominee. Of the 111 Supreme Court justices, 108 have been white males. She is the third woman and first Hispanic Justice.

Ursala Burns became the first AfricanAmerican women to lead a major US corporation (June 2009) succeeding another women, Anne Mulcahy (Xerox).

Anne Giardini became the first female president of Weyerhausser, the large US forest products company in 2008.

Sarah Thomas became the first female to officiate an end of year US college football bowl game, though it was a relatively minor bowl game. There were five women officials in major college football in 2009.

India (June 2009) elected its first female speaker of their parliament (Meira Kumar), termed as a tribute to the women of India for 
the contributions they have make to their country.

Lithuania elected its first female president in May 2009, 53 year old Dalia Grybavskavite

Laura Chinchilla was elected to become the first female president of Costa Rica in February 2010

First Lady Michelle Obama launched a USD campaign against childhood obesity in February 2010. She joined a long list of First Ladies who had important causes in the past.

The first woman was elected to the Kuwait parliament in 2009.

Saudi Arabia appointed its first women minister, Nora bind Abdulla hal-Fayiz, as Deputy Education Minster of a new department for female students. Yet women in Saudi Arabia today are still not allowed to drive.

The Iranian leadership appointed three women ministers in August 2009, the first women appointments since the Islamic Revolution in 1979, but some Iranians have raised doubts abut their motivations as well as the qualifications of two of the three women nominated.

Women are making great progress on the boards of not-for-profit organizations in $\mathrm{Ca}$ nada, with a representation about equal to men's (2008 study conducted by Pat Bradshaw in Canada of 240 boards)

The Egyptian parliament (June 2009) passed a law giving women a 64 seat quota in the lower chamber, one-eight of the total (56 out of the 518 member assembly).

Muslim women in Indonesia are making significant gains as both managers and entrepreneurs.

Women now are just as ambitious as men and desirous of more job responsibilities. To the same degree as men according to a New York-based. Families and Work Institute study.
More women of child-bearing age (24-44) are now in the North American workforce, spurred in part by job losses of men.

Collins (2009) chronicled changes in the lives of American women over a 50 year period indicating areas of progress and stories of pioneering women. In 1960 American women could not get a credit card without their husband's permission and signature. In addition, The Economist (December 2009) wrote a cover story titled "Women power". A very popular US television program Mad Men, located in the advertising sector and based in the 1960s shows "'men as men" (macho, sexually harassing) and "women as girls". The fact that things are a bit different now may be taken as a reflection of progress being made by women?

Carlson, Kacmar and Whitten (2006), in a short note published in the Harvard Business Review, compared results from the same survey administered to managerial women and men in 1965, 1985 and 2005, covering a 40 year period. They reported the following trends

+women and more men have positive attitudes towards women in management

+women and more men (almost equal now) feel comfortable in working for a women.

+more women than men agree that a women has to be exceptional to succeed in business today.

+more women than men think that the business community will never wholly accept female executives

This perception gap is similar to that reported by Ragins, Townsend and Mattis (1998) a few years ago. In addition, these are only words. We need actions on the part of male managers and their organizations to make a difference.

Women were active in Iran's resistance movement in the recent election result controversy (June 2009). Zahra Rahnavard, wife of candidate Mir Hossein Mousavei, an author, Professor, sculptor and political advisor, 
was active in both his campaign and the "resistance"

Having more women in senior corporate jobs and on boards of directors is a possible solution to the economic mess that advanced countries found themselves in 2008. Women are less macho, less aggressive and more risk averse. Women tend to tone down mixed group discussions. Would the fiasco at Lehman Brothers in the US have occurred if the firm was Lehman Sisters, or Lehman Sisters and Brothers? Huang and Kisgen (2009) fond that companies having female Chief financial Officers (CFOs) fared better over the past few years than companies having male CFOs. Companies with female CFOs made fewer acquisitions, and acquisitions made by female CFOs made returns about $2 \%$ higher than hose made by male CFO firms. Female CFOs seemed to undertake greater scrutiny and show less arrogance in acquisition decisions. In addition, female CFOs issued debt less frequently and their debt and equity issuances had higher returns.

There is some evidence that having more women on boards of directors and in senior management jobs may be associated with better organizational performance but the reasons for this are open to debate. A study recently conducted in France showed that companies having $38 \%$ or more women in executive jobs had their stock fall less in 2008 than companies with a smaller percentage of women executives. A Norwegian study showed that having more women on corporate boards was associated with high levels of organizational innovation because women added new perspectives to board deliberations and women took great pains to be prepared for their board deliberations..

Groysberg (2008), in a longitudinal study of "star" stock analysts who changed jobs found that more women than men maintained their superior job performance in their new jobs. Women were less tied to their work environments for their success. In addition, women were more interested in their external than internal relationships. Women also did more advance research on their new companies resulting in a better fit.. Organizations having a more female friendly environment had an obvious advantage here..

I, and several colleagues, have undertaken comparisons of males and females in five countries ( Australia, Canada, China, Egypt, Turkey) in various occupations (e.g., physicians, hotel managers, manufacturing managers, psychologists, managers and professionals in a variety of industries) and though there were always differences on personal and work situation factors (e.g... age, income, organizational level), males and females were generally similar on work satisfactions and psychological well-being outcomes (sexual harassment was not included in these studies).

The business media increasingly has stories about executive-level men that are attempting to change their organizational cultures to make them more welcoming of talented women. In addition, organizations in several countries that are making efforts to "level the playing field" are being profiled. Some men and some organizations "get it".

Women as a critical source of talent In Japan, only $0.8 \%$ of CEOs are women. versus $10 \%$ in the UK. Less than $10 \%$ of Japanese managers are women versus $43 \%$ in the US. Japan is facing a severe shortage of talent, and Japan does not encourage immigration. So to address the talent gap, it is vital for Japan to do a much better job advancing qualified women.

Women as drivers of the world economy. Silverstein and Sayre (2009a, 2009b) observe that women control $\$ 20$ trillion in consumer spending and this figure is expected to increase. In addition, women earn about \$13 trillion in total yearly income and this figure will also rise. Women make the major purchasing decisions in several areas (e.g. home furnishings, vacations, automobiles). Women represent the largest market opportunity in the world. Yet women get little help at home and are too often ignored by manu- 
facturers and service providers. Women are likely to have more power in the future.

One can make the case that bringing about equal opportunities in the workplace would double the IQ of such countries. There are some countries where only small differences exist in male and female employment rates (e.g., Sweden, Denmark, France, Germany, the US) while other countries have larger differences (e.g., Italy, Japan).

Several interrelated factors have contributed to the gains that women have made in the work force. These include the emergence of feminism, a greater demand for labor in knowledge work where women can perform as well as men, more women in higher education, more people comfortable with women in the workforce and with women sometimes earning more than men, a greater availability of flexible work hour, and work-family programs, and greater use of labor-saving technologies and appliances in the home.

\section{Now the bad news.}

On the work front, while women make up $59.6 \%$ of the US labor force, they held only $15.7 \%$ of corporate officer jobs in 2008 , (15,.4\% in 2007, and $11.7 \%$ in 1998) (Catalyst Fortune 500 Companies). Building on the Collins (2009) book, "We've come a long way, baby - but we still have a long way to go." Women still encounter prejudice, need to "choose" between careers and mother hood, pay a price for choosing motherhood, opt to not have children, spend less time with their children than they would like to, and as a consequence are more likely than men to "drop out" of the workforce

Development Dimensions International studied 12,000 managers in 26 countries and found $28 \%$ more men than women were in early career high potential programs and $50 \%$ more men than women were in executive level high potential programs. Women were underrepresented in high potential leadership development programs.
A study of the financial services industry in the UK revealed (April 2009) significant pay differences between women and men

Women do more housework and shoulder more family responsibilities than do men (Hochschild; 1989; Rubinstein, 2009)

Having children, particularly among women with more education, resulted in large drops in income. Childless women earned more money than did women with children. This difference was considerably smaller among women with or without children but low levels of education (Canadian data from 1993-2004; Statistics Canada).

Women with children who travel as part of their jobs are viewed differently than men with children who travel as part of their jobs. This was sparked by a recent incident in Canada where a court judge downplayed testimony of a women professional as she was traveling as part of her job and leaving her children at home (though well cared for).

Surveys in Canada's financial services sector (June 2009) showed little gain over the past eight years in women's progress.(surveys every 2 years beginning in 2000, by Catalyst).

\section{Investment dealers-holding line positions}

Retail (private client positions), $16 \%$ were women in 2000; 20\% were women in 2008

Women in capital markets $-37 \%$ in 2000 , $39 \%$ in 2008.

The biggest obstacles to women were reported to be the long work hours, and having children. Hoobler, Wayne and Lemmon (2009), reported that both female and male managers mistakenly believed that women had to deal with higher levels of family-work conflict than did men, servicing as a barrier to women's career progress. .

In North America, four highly publicized studies of women in capital markets (the financial sector) undertaken by Catalyst have produced little change-should this be worrisome to us. We have argued that it is vital to keep corporate North America's feet to the fire. 
The Harvard Business Review, concluded (May 2009), based on survey of 500 companies in 2008, that candidates for senior executive positions typically went through only 1 to 5 interviews (32\%) and half relied on the hiring mangers "gut feeling" (a feeling that the candidate had what it takes to be successful in any job) So much for objectivity, data, and similarity-attraction.

A recent longitudinal study of more than 500 women reported by McLaughlin, Uguss and Blackstone (2009) found that female managers faced more sexual harassment at work than do women with no supervisory responsibilities $(50 \%$ versus $33 \%$ ) because male co-workers target them to equalize power in the workplace.

"Girls today have never had it so good, right.....There really are no glass ceilings despite the fact that some of you moan about it all the time."

Sir Stuart Rose, Chairman of British department store Marks and Spencer, in an indepth and very candid interview with the Guardian Observer magazine. A poll, in response to this story, on the Guardian's website, found that $49 \%$ of readers agreed with him.

Although there is considerable evidence that female physicians provide better care to their patients than do male physicians (e.g., better listeners, take more time with patients), the medical profession in North America believe that female physicians are lowering productivity. Female physicians work fewer hours than do their male colleagues and process fewer patients in a given time than do their male colleagues.

Are we having fun yet? A recent study carried out in the US found that women in general were now reporting less happiness than men, and less happiness than they did earlier, despite women's advancements and gains .Men's level of happiness had also dropped. Why should this be? It may be a matter of expectations. Women many be working too hard, not having enough enjoy- ment, and perhaps women are unhappy over pay and other discriminations. Does "having it all" mean "doing it all" for women? Is it a matter of "the grass always looks greener on the other side of the fence"? Now that women are working with men in the same arenas, do women come to see that it isn't as much fun as they thought it might be. It is unlikely, however, that women would choose to go back to the old days.

Women + power $=$ discomfort. Only $20 \%$ of elected officials in Canada are women. Bashevkin (2009) attributes this to a discomfort that men have with women in power. In Canada, women are twice as likely to be elected to public office in urban rather than rural ridings. Reflects the conservatism in rural ridings (greater discomfort, less openness to what is different).

Kornblut (2009) analyzed the US presidential race of 2008 in which two female candidates (Hilary Clinton and Sarah Palin) were involved; Clinton seeking the Democratic nomination eventually garnered by Barack Obama, and Palin being the Vice-Presidential candidate of the Republican party. Kornblut argues that both Clinton and Palin "lost" because of gender. Commentators noted their hair, clothing, how they would manage their families, and role of their husbands. There was a double standard in the way male and female politicians are treated. For example when Palin resigned as governor of Alaska some commentators raised the question of "psychological issues"; when Dole resigned from the Senate to run for President, pundits offered no analysis of his decision.

Boys will be boys? A video of Erin Andrews, an attractive side-line sports reporter for ESPN in the US (July 2009), when she was walking or standing naked in a hotel room emerged on the internet. Some one drilled a hole in the wall and secretly taped her. Sports is an industry of men writing and talking about the activities of other men. Women sports reporters are still viewed as cheerleaders, sideline reporters or ignored 
Play equity? In Canada, women continue to have difficulties obtaining important artistic positions. In 1982, women constituted $10 \%$ of produced playwrights in Canada; $13 \%$ of directors, and $11 \%$ of artistic directors. Women were often found in administration, typically as general managers Over 25 years later little has changed. In some parts of Canada, $83 \%$ of artistic directors are men, as are $79 \%$ of playwrights, and $67 \%$ of directors. Women tend to be directors in smaller, more peripheral theatre companies.

Plays written by women, but for purposes of the research, were identified and said to be written by equal number o women and men, were sent to artistic directors. Male directors gave male and female authorship similar ratings; female artistic directors gave lower ratings to the scripts written by females.

There are very few female film directors. Women are more interested in making films that do not fit into the action blockbuster category. When a movie directed by a female director "flops" it is usually more strongly and negatively criticized than "flops" made by male film directors. In addition, most female directors do not have the money to pursue film making. Only $12 \%$ of film directors are female.

With friends like these? There has been some recent writing (Mooney, 2005) on female bullies the workplace individuals similar to the Meryl Streep character in "The devil wears Prada." Apparently female bullies target female victims $71 \%$ of the time according to a 2007 survey conducted by the Workplace Bullying Institute, a US advocacy and polling firm

\section{Discrimination against women}

Mazin al-Shihan, director of a city agency in Baghdad developed a plan to pay men to marry Iraqi war widows. Here is his rationale.

"If we give the money to the widows, they will spend it unwisely because they are uneducated and they don't know about bud- geting. But if we find her a husband, there will be a person in charge of her and her children for the rest of their lives."

An 8 year old girl in Pheonix was raped by four young boys from Liberian families. The girls father, also from Liberia, said he did not want his daughter back. (July 2009)

Only $18 \%$ of Afghan women can now read or write. This prevents them from undertaking even the simplest tasks such as counting money. The Taliban banned all girl's education from 1996 to 2001 when they were in power. Taliban recruits were attacking girl's schools as this chapter was being written. Girl's education in Afghanistan suffered a setback in May 2009 when schools north of Kabul were attacked with gas sending almost 150 students to hospital. Frightened parents were now keeping their daughters at home.

\section{Violence against women}

George Sodini went into a gym in Pennsylvania with guns and ammunition and killed 3 women, wounding 9 others before committing suicide.(August 2009). Sodini developed a hatred for women as a result of his difficulties in meeting women and developing a long term relationship with them. In Monteal Canada, more than a decade ago, a young man named Marc Lepine entered a university classroom with a weapon, asked the men to leave, then shouting anti-feminist statements killed over a dozen young women.

A Saudi judge, speaking at a conference on domestic violence told the audience that a man had the right to slap his wife if she spent money wastefully and said that women were equally to blame for increased spousal abuse. These remarks, while not an element of their law, carry weight since Saudi judges, who are also Islamic clerics, are respected.

A Saudi Arabian man, aged 50, married an 8 year old girl in the summer of 2008 against the wishes of her mother. The man was 
a friend of the girl's father and was paid $\$ 16.000$ in return. The girl was granted a divorce from the man in mid-2009. Saudi Arabia, though receiving criticism from many countries for this practice, still permits child marriages. However they have now raised the age to 14 .

\section{Culturally approved violence against women}

In the Sudan, 10 women were flogged in public for wearing trousers in violation of the country's strict Islamic law. One of these women, Ludna Hussein, is pursuing her case in court to expose the violent treatment of women in her country. (July, 2009) Other countries having similar laws include Saudi Arabia, Pakistan, Iran and in the most conservative areas of Afghanistan.

Afghanistan (August 2009) is considering a law in which women can be denied food and money if they do not have sex with their husbands. An earlier version of this law allowed men to rape their wives if they refused sex (in the Shiite community).

About 200 women in Turkey die each year as a result of honour killings (Mojad \& Abdo, 2004). In some parts of the country, Turkish women dishonour their families by wearing tight clothes, having unauthorized contact with young men, or falling victim to rape. Some women are buried alive with their hands tied behind their backs. Others are locked in a room, given rat poison, a rope, or a gun and told to kill themselves to spare a family member from legal retribution.Honour killing is part of larger culture of gendered or patriarchal violence with is a global phenomenon common in Middle-Eastern and South-Asian countries. Honor-related violence is sometimes given legal sanction in the form of lighter sentences or complete leniency Honor crimes are premeditated and often involve several family members following considerable planning. Both religion and culture are likely related to such violence.

Honor killings, including violence against women termed "ideological terrorism." have taken place in Canada. But these have also taken place in Muslin, Sikh, Hindu and south Asian Christian communities. Honor killing-adultery, limiting a woman's liberty to choose her own life style. Women have been killed for engaging in remarital sex , extra-marital sex, and being the victims of a sexual assault. These acts, reflecting gender bias, an imbalance of power and efforts to control, enforce what men believe what women should be doing.

An Afghan family living in Montreal has been charged with the murder of four women including three of their daughters. The parents charged, along with a son, were upset and angered by one of their daughters dating a young man form Pakistan that they did not approve of (July 2009).

Culturally approved violence -women are threatened, strangled, locked away, married to strangers. The general preference in these countries is for males over females,

Rape and sexual slavery as an instrument of war in several countries (e.g., Liberia)

Hundreds of women in Bangladesh have had acid thrown on then for refusing a sexual advance, failing to pay significant demanded dowries, or family disputes over land. These events also take place in Pakistan.

Attacks in schools in Afghanistan by the Taliban (May 2009) have more parents keeping their daughters at home. Two gas attacks at schools sent almost 150 students to hospitals. Only $18 \%$ of Afghan women can read and write making it difficult for them to perform even basic tasks (e.g., counting money).

There has been a sharp increase in the number of Afghan women, mainly in their early 20s, who are increasingly turning to suicide to deal with the violence and brutality they face in their daily lives.

The Taliban banned all girls education when they were in power in 1996-2001.Afghan women are concerned (February, 2010), that efforts to include the Taliban in the Kar- 
zai government will set back some of the recent gains made by Afghan girls and women.

Hypocritically, Muslim men from the Gulf States go to Bahrain where they can drink alcohol and use the services of prostitutes.

"How did 100,000,000 women disappear? This was a headline in the Toronto Star, Saturday, June 6, 2009, IN1, IN5. The United Nations Population Fund stated that over 60 million girls are "missing" from various countries in Asia.

Researchers have discovered that he ratio of women to men in developing countries and in some cultures fell below average (India, sub-Saharan Africa). Hundreds of millions of women in these countries are dead-victims of violence, discrimination, and neglect. These women are dead because their lives were given little value; the strongest indication of discrimination. These women were denied access to health care, food and social services.

Most of this excess mortality occurred later in life: $66 \%$ in India, 55\% in /China, and $83 \%$ in sub-Saharan Africa (HIV AIDS, suicide, murder, not given hospital care when sick). It has been thought that the absence of women occurred in early childhood (infanticide). Female infanticide has been a concern in India and China for several years.

\section{Limited support for women}

In Italy, there is little support for childcare. This results in Italy having a low fertility rate and low levels of female employment particularly in the child-bearing years.

Ferrera (2008), in his recent book titled “The W factor -why women's work will help Italy to grow" makes the case why supporting women in the workplace will be vital to Italy's economic progress in the future.

\section{Implications \\ "Women are the most under-utilized natural resource in the world"}

CARE

There are some tangible signs of progress, though uneven, and indications of stalling and back-sliding. More women are now in the workforce. More women are getting the necessary education and experience to equip them for success in the workforce. The fact that we are still chronicling "firsts" however is disappointing.

The bad news includes evidence showing little and slow progress in women's career advancement, some back-sliding, lots of words but little action or follow through, along with a series of worldwide events that highlight some deeply rooted societal biases against women, becoming fatal in specific instances. Kristoff and Wudunn (2009) describe a hatred towards women that seems to be present in some countries. Very few organizations have undertaken initiatives to support the advancement of women in most of the world's countries. It may be that the time between this and our 2004 volume (6 years) is not long enough to see progress and change.

My focus on managerial and professional women reflected, in part, my affiliation with leading schools of business and management. Our female students might someday become successful managers and professionals. In addition, I live in Canada, a developed industrialized and advanced country. Women in my country, while facing unique challenges because of their gender, are also supported in several important ways. This legitimate emphasis, however, blinded me to the reality of a significantly larger number of women in the workplace. In addition, appreciating the reality and experiences of these women in a wider range of countries highlighted the huge challenges these women face and how addressing these obstacles is also likely to advance the cause of 
their more educated and priviliged "sisters". The work and life experiences of women in several countries in the developing world indicated many distressing features (bias, hostility towards women, huge restrictions on their choices). Sadly, women worldwide still lack basic rights such as education, freedom from violence, opportunities to pursue taken for granted life options, and justice in the workplace.

I had assumed that supporting the advancement of women into management and professional jobs would influence the experiences of women in all walks of life. This does not seem to have happened. Perhaps supporting women facing hatred, hostility and discrimination represents a more fruitful starting point that might, in time, influence the numbers of women in management and the professions.

Several of the "bad news" articles came from particular countries (e.g., Afghanistan, Saudi Arabia). My intention is not to single out these countries or there religions but rather paint a picture of women's experiences world-wide. I hope, in time, that the circumstances in these, and other countries, would change to provide a higher quality of life and access to more opportunity among women and girls in these countries.

I believe that efforts must be made along at least two inter-related tracks simultaneously if greater progress for women worldwide is to be realized. One track involves a continuation of our efforts to support the education and advancement of women into managerial and professional jobs. The second track is to tackle the pervasive negative attitudes, behaviors and hatred that face women worldwide.

It is no coincidence that countries among the least prosperous in the world display the greatest hatred for their women. Landes (1999) suggests that the best indicator of an economy's growth potential is the legal rights and status of its women. He writes that denying women deprives a country of both labor and talent while undermining the motivation to achieve of boys and men. Boys and men who believe they are superior and entitled do not need to learn and achieve.

Efforts need to be made at the macrolevel (societal) before significant progress will be seen at the levels of individual women. In addition, obstacles and barriers must be tackled at several levels simultaneously. These include: education beginning in the early formative years, and socialization in families and schools

On the research front, there is an urgent need to undertake projects on the experiences of women, not only in management but at all levels and walks of life(and including men as well) that includes a small number of countries and also examines indicators of country/society cultural values (Burke, 2009; Emerich, Denmark \& Den Hartog, 2004). The work of Hofstede $(1980,1998)$, and the GLOBE project (House, Hanges, Javidan, Dorfman \& Gupta, 2004) has identified some of these cultural values (e.g., masculinity, egalitarianism).

We must continue to put pressure on our government leaders to support women in all countries of the world. Institutions such as the United Nations. World Bank, International Monetary Fund, International Labour Organization, and the Organization for Economic Cooperation and Development need to support such initiatives by collecting statistics on the experiences of all women in various. countries. 


\section{References}

Barreto, M., Ryan, M. K., \& Schmitt, M. T. (2009) The glass ceiling in the 21zxt century: Understanding barriers to gender equality. Washington, DC: American Psychological Association.

Bashevkin, S. (2009) Women, power, politics: The hidden story of Canada's unfinished. democracy. Oxford: Oxford University Press.

Burke, R. J. (2009) Cultural values and women's work and career experiences. In R S.Bhagat \& Steers, R. M. (eds.) culture, organizations, and work. Cambridge: Cambridge University Press. pp.442461

Burke, R. J., \& Mattis, M. C. (2007) Women and minorities in science, technology, engineering and mathematics: Upping the numbers. Glos, UK: Edward Elgar.

Burke, R. J., \& Mattis, M. C. (2005) Supporting women's career advancement: Challenges and opportunities. Glos, UK: Edward Elgar.

Burke, . J., \& Nelson, D. L. (2002) Advancing women's careers: Research and practice. Oxford,UK: Blackwell.

Burke, R. J., \& Mattis, M. C. (2000) Women on corporate boards of directors: International challenges and opportunities. Dordrecht, NL: Kluwer.

Carlson, D. S.,, Kacmar, K. M., \& Whitten, D. (2006) What men think they know about executive women. Harvard Business Review, 89, 78-79.

Catalyst (1998) Advancing women in business: Best practices from the corporate leaders. San Francisco: Jossey -Bass

Collins, G. (2009) When everything changed: The amazing journey of American women from 1960 to the present. New York: Little, Brown and Company.
Davidson, M. J., \& Burke, R. J. (2010) Women in management worldwide: Progress and prospects. Hants, UK:Gower Publishing. in press.

Davidson, M. J., \& Burke, R. J. (2004) Women in management worldwide: Facts, figures and analysis. Hants, UK: Ashgate.

Eagly, A. H., \& Carli, L. L. (2007) Through the labyrinth: The truth about how women become leaders. Boston: Harvard Business School Press.

Economist (2009) Women power. London: The Economist. December.30.

Emrich, C.,G., Denmark, F. L., \& Den Hartog, D. N. (2004) Cross-cultural differences in gender egalitarianism. In R. J. House, P. Hanges, M. Javidan, P. Dorfman \& V. Gupta (eds.) Culture, leadership and organizations.: The GLOBE study of 62 societies. Thousand Oaks, CA: Sage Publications. pp. 343-394.

Ferrera, M. (2008) Why women's work will help Italy to grow. Milan: Mondador.

Groysberg, B. (2008) How star women build portable skills. Harvard Business Review, 86, 74-81.

Hochschild, A. R. (1989) The second shift. New York: Avon Books..

Hofstede, G. (1998) Masculinity and femininity: The taboo dimensions of national cultures. Thousand Oaks CA: Sage Publications.

Hofstede, G. (1980) Culture's consequences: International differences in work-related values. Newbury Park, CA: Sage Publications.

Hoobler, J. M., Wayne, S. J., \& Lemmon, G. (2009) Bosses' perceptions of familywork conflict and women's promotability: Glass ceiling effects. Academy of Management Journal, 52, 939-957. 
House, R. J., Hanges, P. J., Javidan, M., Dorfman, P. W., \& Gupta, V. (2004) Culture, leadership and organizations: The GLOBE study of 62 societies. Thousand Oaks, CA: Sage Publications.

Huang, J., \& Kisgen, D. J. (2009) Gender and corporate finance. Working Paper, Carroll School of Management, Boston College, Boston.

Kornblut, A. E. (2009) Notes from the Cracked ceiling: Hilary Clinton, Sarah Palin, and what it will take for woman to win. New York: Crown Publishing.

Kristoff, N.D, \& WuDunn, S. (2009) Turning oppression into opportunity for women worldwide. New York: Knopf.

Landes, D. S. (1999) The wealth and poverty of nations: Why some are so rich and some so poor. New York: Norton.

McLauglin, H., Uguss, C., \& Blackstone, A (2009) A longitudinal analysis of gender, power and sexual harassment in young adulthood. Annual Meeting of the American Sociological Association, August.

Mojad, S., \& Abdo, N. (2004) Violence in the name of honour: Theoretical and political challenges. Istanbul: Bilgi University Press.

Mooney, N. (2005 ) I can't believe she did that!: Why women betray other women. at work. New York: St. Martin's Press.

Ragins, B. R, Townsend, B., \& Mattis, M. C. (1998) Gender gap in the executive suite: CEOs and female executives report on breaking the glass ceiling. Academy of Management Executive, 12, 28042,

Rubenstein, C. (2009) The superior wife syndrome: Why women do everything so well and why - for the sake of our marriages -we have got to stop. New York: Simon \& Schuster.
Silverstein, M. J, \& Sayre, T. K. (2009a) The female economy. Harvard Business Review, 87, 46-53.

Silverstein, M. J., \& Sayre, T. K. (2009b) Women want more: How to capture your share of the world's largest market. New York: Harper Collins.

Vinnicombe, S., Singh, V., Burke,R. J., Bilimoria, D., \& Huse, M. (2009) Women on corporate boards of directors: International research and practice. Glos, UK: Edward Elgar. 
